\title{
Costs of healthcare-associated infections in an Intensive Care Unit
}

\author{
Custos das infecções relacionadas à assistência em saúde em uma Unidade de Terapia Intensiva \\ Costos de infecciones relacionadas a la atención de salud en una Unidad de Terapia Intensiva
}

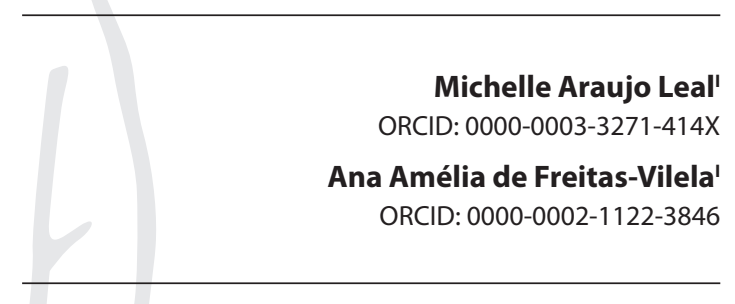

'Universidade Federal de Jataí. Jataí, Goiás, Brazil.

How to cite this article:

Leal MA, Freitas-Vilela AA. Costs of

healthcare-associated infections in an Intensive Care Unit.

Rev Bras Enferm. 2021;74(1):e20200275.

doi: http://dx.doi.org/10.1590/0034-7167-2020-0275

Corresponding author:

Michelle Araujo Leal

E-mail:mi-leal@hotmail.com

EDITOR IN CHIEF: Antonio José de Almeida Filho ASSOCIATE EDITOR: Hugo Fernandes

Submission: 06-01-2020

Approval: 09-24-2020

\begin{abstract}
Objectives: to evaluate hospitalization costs of patients with and without HealthcareAssociated Infections an Intensive Care Unit. Methods: a retrospective case-control study. Data collection was retrieved from the medical records of Intensive Care Unit of a mediumsized public hospital in Goiás-Brazil. For each case, two controls were selected. Data on socioeconomic, clinical, and hospital costs were collected. To verify associations between variables, Odds Ratio and linear regression were calculated. Results: a total of 21 patients diagnosed with Healthcare-Associated Infections and 42 controls were evaluated. The hospitalization cost for patients with infection was four times higher than for non-infection patients ( $p$-value $<0.001)$. There was an association between infection and higher mortality ( $p$-value $<0.001)$, longer hospital-stay ( $p$-value $=0.021$ ), and higher hospital costs ( $p$-value $=0.007$ ). Conclusions: hospitalization costs of diagnosed Healthcare-Associated Infections patients are high compared to those who do not have this diagnosis.

Descriptors: Intensive Care Units; Health Care Costs; Infections; Delivery of Health Care; Critical Care.
\end{abstract}

\section{RESUMO}

Objetivos: avaliar custos de internação hospitalar de pacientes com e sem Infecção Relacionada à Assistência em Saúde em uma Unidade de Terapia Intensiva. Métodos: estudo caso-controle retrospectivo. Os dados foram coletados dos prontuários da Unidade de Terapia Intensiva de um hospital público de médio porte em Goiás-Brasil. Para cada caso foram selecionados dois controles. Foram coletadas informações socioeconômicas, clínicas e custos hospitalares. Para verificar associações entre variáveis foram calculados Odds Ratio e regressão linear. Resultados: foram avaliados 21 pacientes com diagnóstico de Infecção Relacionada à Assistência em Saúde e 42 controles. O custo de internação de pacientes com infecção foi quatro vezes maior em relação aos pacientes sem infecção ( $p$-valor $<0,001)$. Houve associação entre infecção e maior mortalidade ( $p$-valor $<0,001)$, maior permanência hospitalar ( $p$-valor $=0,021$ ) e maior custo hospitalar ( $p$-valor $=0,007$ ). Conclusões: custos financeiros de internação de pacientes diagnosticados com Infecção Relacionada à Assistência em Saúde são elevados em relação àqueles sem este diagnóstico.

Descritores: Unidades de Terapia Intensiva; Custos de Cuidados de Saúde; Infecção; Assistência à Saúde; Cuidados Críticos.

\section{RESUMEN}

Objetivos: evaluar costos de internación hospitalaria de pacientes con y sin Infección Relacionada a la Atención en Salud en una Unidad de Terapia Intensiva. Métodos: estudio casocontrol retrospectivo. Datos recolectados de historias clínicas de Unidad de Terapia Intensiva de un hospital de tamaño intermedio de Goiás-Brasil. Para cada caso fueron seleccionados dos controles. Se recolectaron datos socioeconómicos, clínicos y costos hospitalarios. Para verificar asociaciones entre variables, se calcularon Odds Ratio y regresión lineal. Resultados: fueron evaluados 21 pacientes con diagnóstico de Infección Relacionada la Atención en Salud y 42 controles. El costo de internación de pacientes con infección fue cuatro veces mayor respecto de los pacientes sin infección ( $p$-valor $<0,001$ ). Existió asociación entre infección y mayor mortalidad ( $p$-valor $<0,001)$, mayor permanencia hospitalaria ( $p$-valor $=0,021)$ y mayores costos hospitalarios ( $\mathrm{p}$-valor $=0,007$ ). Conclusiones: costos financieros de internación de pacientes diagnosticados con Infección Relacionada a la Atención en Salud son elevados respecto de aquellos sin tal diagnóstico.

Descriptores: Unidades de Cuidados Intensivos; Costos de la Atención en Salud; Infecciones; Prestación de Atención de Salud; Cuidados Críticos. 


\section{INTRODUCTION}

Hospital infection is an infection related to a hospitalization or hospital procedures and can occur after the patient's hospital admission, during hospitalization or after discharge ${ }^{(1)}$. The term "hospital infections" has been replaced by "Health CareAssociated Infections" (HAls), a term that encompasses infections acquired and related to care in any environment ${ }^{(2)}$.

HAls are among the most recurrent complications of hospitalization. They are associated with the use of invasive devices (venous accesses, probes, tubes and others), surgical procedures and infections by multidrug-resistant microorganisms, which currently represent a serious threat to the patient's health, as they make rehabilitation difficult, especially for patients who are already under intensive care $^{(3)}$.

According to the World Health Organization (WHO), HAls are one of the most common adverse events in health care with an impact on mortality and quality of life for the population. The risk of acquiring at least one type of HAls is present in up to $7 \%$ and $10 \%$ of patients in developed and developing countries, respectively ${ }^{(4)}$.

In the United States, the Centers for Disease Control and Prevention (CDC) of Atlanta, through the SENIC study (Study on the Efficacy of Nosocomial Infection Control), evaluated the effectiveness of HAls control programs active in the country. It was verified that HAls extend hospital stay by at least four days and increase additional costs ${ }^{(2)}$.

Guest and collaborators ${ }^{(3)}$ estimated the HAls annual economic impact (2016/2017) served by the National Health Service (NHS) at $£ 2,1$ billion with direct costs only. Direct costs are those spent on hospitalization, and indirect costs are the productivity losses for society, due to absenteeism and mortality ${ }^{(5)}$. In the United States, a total of 1,7 million patients diagnosed with HAls are estimated annually, of which almost 100.000 evolve to death, resulting in costs of more than $U \$ 30$ billion/year ${ }^{(6)}$.

HAls are more severe in high-risk populations, such as the elderly, adults admitted to Intensive Care Units (ICUs) and newborns. Incidence rates of HAls in ICUs in developing countries exceed those of developed countries, mainly due to lack of resources and little knowledge in epidemiology and infection control ${ }^{(7-8)}$.

In studies conducted in Brazil, there were a high cost of patients with HAls admitted to the ICU. In Goiânia-GO, the cost of hospital stay in the ICU of HAI patients was 20,4 times higher compared to patients without HAI. This study evaluated only bloodstream infection ${ }^{(9)}$. In the state of Minas Gerais, the average cost of HAI patients in the ICU was $R \$ 9.763,78$ versus $R \$ 1.093,94$ for patients without HAI ${ }^{(10)}$.

Data on hospitalization costs for all types of HAls in an adult ICU in Brazil are scarce. It was evaluated, in the northern region of the state of Paraná, the economic impact of HAl on the cost of hospitalization of children from July to December of 2015. The authors found that the costs of HAl patients during hospitalization were 4,2 times higher than those without it ${ }^{(6)}$. In Resende, in the state of Rio de Janeiro, a research investigated the total cost of patients in an ICU and found that $38.4 \%$ of this amount was assigned to the treatment of HAl patients acquired in the ICU, $35.7 \%$ for patients who have already admitted with infection and $25.9 \%$ for patients without infection ${ }^{(11)}$.
Data on costs in the ICU are scarce and evaluated, mainly, in large Brazilian centers, being limited/nonexistent the studies in cities in the interior of the states of the Brazilian Midwest Region. Also, there was a scarcity of studies that compared the financial cost between adult HAI patients and without this diagnosis admitted to the ICU.

\section{OBJECTIVES}

To evaluate the costs of hospitalization of HAI patients in relation to patients without HAls in an ICU.

\section{METHODS}

\section{Ethical aspects}

Ethical principles involving research with human beings were followed, following Resolution no. 466 of 2012 of the National Health Council of the Ministry of Health. Signing the informed consent form was waived by the Research Ethics Committee (CEP - Brazilian acronym), and the study was approved by the CEP of Goiás Federal University.

\section{Design, period, and study setting}

This is a retrospective case-control study of patients' medical records. It was carried out in an ICU consisting of six beds of a medium-sized public hospital in the city of Jataí, located in the southwest region of the state of Goiás, Brazil. For the selection of cases and controls, the medical records of patients hospitalized between January and December of 2015 with a hospital stay longer than 72 hours were evaluated.

The manuscript followed the checklist of items that should be included in the reports of the case-control studies, using the STROBE tool.

\section{Population, inclusion, and exclusion criteria}

The present study consisted of adult individuals (aged 18 years or over), of both sexes. Everyone who had a diagnosis of HAl (case group) during 2015 was included. The HAl diagnosis of patients (a group of cases) was made by the Commission for Infection Control Related to Health Care (CICRHC) of the institution, after being admitted to the ICU.

The control group was composed of patients with characteristics similar to the case group. The characteristics evaluated were age group, month and hospitalization period. For each case, two patients were selected as controls. It was constituted as inclusion criteria for patients in the control group: age 18 years or older; the same month of hospitalization of the HAl patient; and hospital stay similar and not superior to the HAI patient.

\section{Study protocol}

It was collected variables of interest from the patient's medical record using an instrument developed by the authors, including the following variables: sex (male/female), age (18-40; 40-60 and 60 and over), marital status (single, married or living with a partner, widower), skin color (black, white, brown, yellow, indigenous), 
diagnosis of ICU admission (based on the International Classification of Diseases - ICD-10), days of total hospital stay (days), length of stay in the ICU (days), use of antimicrobials (yes/no), topography/ type of hospital infection, invasive procedures (yes/no), isolated microorganism, outcome of hospitalization (discharge to another ward, discharge from hospital, transfer to another institution, death), risk factors and comorbidities (yes/no).

For the analysis of hospital costs, the cost of hospitalization was collected. Each patient had a billing form with a description of the procedures performed, but the costs of each procedure were not discriminated or stratified. The costs were described in hospital services and professional, such as physiotherapy assistance, disease treatment, dialysis treatment, daily rates, transfusion medicine, transfusion medicine patient exams, trachea and bronchus, general costs, test performed outside the structure, access to dialysis, hemodialysis, ultrasounds, doctor's appointments/other, blood products, chest and limb tomography, abdomen and pelvis tomography, chest wall, anesthesia, totaling the cost of hospitalization.

\section{Analysis of results and statistics}

The collected data were analyzed using descriptive statistics, with frequency distribution in absolute numbers and percentage for categorical variables and average and standard deviation for continuous variables. To check the difference between the variables, the chi-square test was applied $\left(x^{2}\right)$ for categorical variables and Student's T-test for continuous variables. To estimate the associations of the variables, were calculated Odds Ratio (OR) association measures. There was an association between hospital cost and the presence or absence of HAl by means of linear regression, and the model was adjusted by the number of days of hospital stay, age, sex, ethnicity, and marital status. These variables were selected because they are the socioeconomic and demographic information collected from the patients' medical records, as they are important variables to assess the profile of individuals most likely to develop HAI. One hypothesis is that patients living in a domestic partnership may have a healthier life and, consequently, a better state of health ${ }^{(12)}$ and less risk of developing $\mathrm{HAl}$. The results of the statistical tests were considered significant for $p<0,05$. The data were analyzed using Epi Info software version 7.0 and Stata version 12.0.

\section{RESULTS}

The total sample in the present study was 63 patients, 21 cases and 42 controls. Of the cases of $\mathrm{HAl}, 52.4 \%$ were female; $76.2 \%$ were non-white (66.7\% brown and $9.5 \%$ black); and $71.4 \%$ did not live with a partner. Regarding age, $57.1 \%$ of HAl patients and $59.5 \%$ of those without HAl had from 18 to 60 years old. There was no significant difference between sociodemographic characteristics and the presence or absence of HAI (Table 1).

The hospitalization cost for HAI patients was four times higher than those without HAls: on average, $\mathrm{R} \$$
$16,132.21$ compared to $R \$ 4,014.26$ for the control patient $(p<0.001)$. Hospital stay and ICU stay were statistically significant in HAI patients. The average (standard deviation - SD) of total days of hospital stay was 35.0 (23.5) for HAl patients, while in the control it reached 12.9 (7.8) days. In the ICU, the average hospital stay was 26.5 (19.4) days for cases and 6.9 (3.9) days for controls, $(p<0.001)$. When stratified, it was found that $38.1 \%$ of HAl patients remained more than 30 days. Among patients without $\mathrm{HAl}$, there was no stay longer than 30 days (Table 1).

The average cost in Real ( $R \$$ ) of all cases was approximately $R \$ 10,000.00$. The cost ranging from $R \$ 1,000.00$ to $10,000.00$ was observed in $38.1 \%$ in cases versus $95.2 \%$ in controls. The costs related to the control case subjects $(2.4 \%)$ ranged from $\mathrm{R} \$$ $10,000.00$ to $20,000.00$. Concerning the other individuals with $\mathrm{HAl}, 28.6 \%$ had a cost of R\$ $10,000.00$ to $20,000.00 ; 19 \%$ from $\mathrm{R} \$$ $20,000.00$ to $30,000.00$; and $14.3 \%$ from $R \$ 30,000.00$ to $40,000.00$. The hospital cost and length of stay were higher among HAI individuals compared to those without HAls (Figure 1).

The main diseases that led to ICU admission, according to the International Classification of Diseases (ICD-10), were grouped into: respiratory diseases; circulatory system diseases; digestive tract diseases; diseases of the urinary tract; infectious and parasitic diseases; neurological diseases and trauma. The most frequent risk factors present at admission were: Systemic Arterial Hypertension, Cardiac Insufficiency and Diabetes Mellitus. There was no significant association between the clinical conditions of patients at admission and the presence or not of HAl. However, there was a borderline association for the HAl onset among patients admitted with infectious and parasitic diseases $(p=0.07)$. and, among those admitted due to trauma, HAl was not observed ( $p=0.09$ ) (Table 2).

Table 1 - Sociodemographic characteristics according to the presence or absence of Health Care-Associated Infections of patients admitted to an Intensive Care Unit, Jataí, Goiás, Brazil, 2015

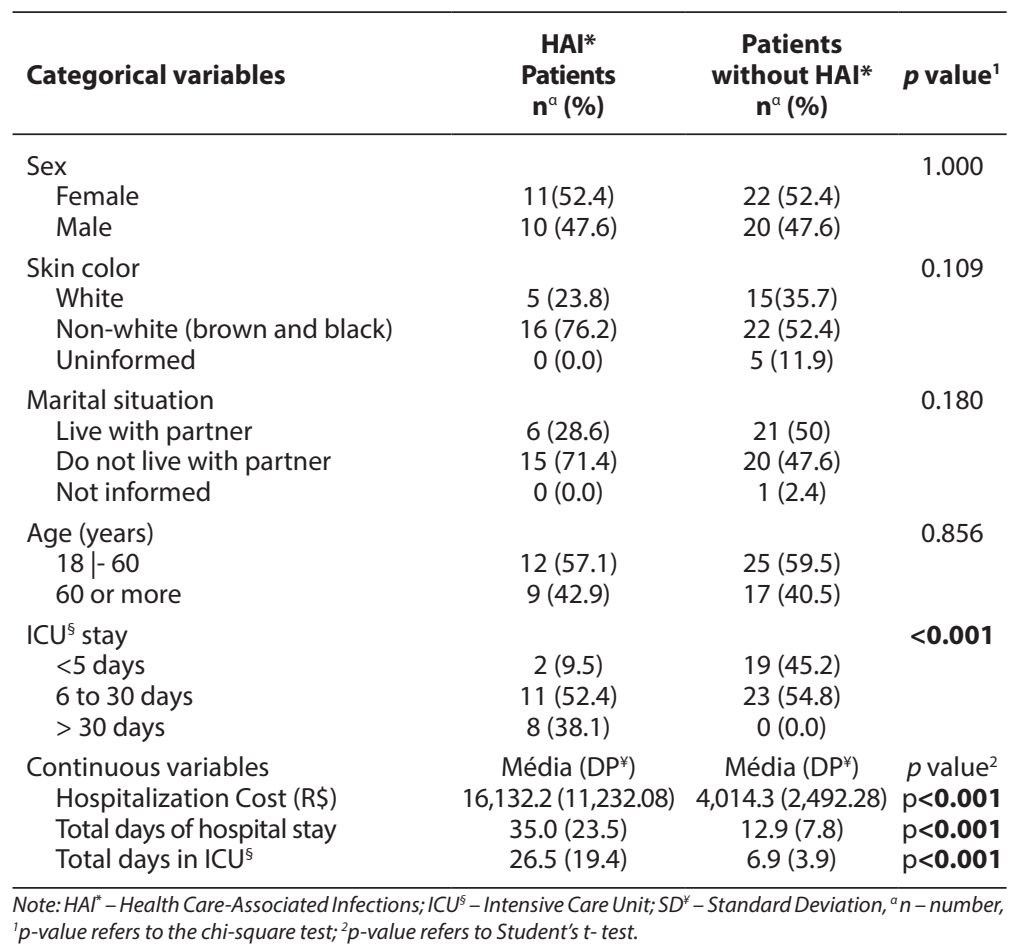


Table 2 - Clinical conditions of the patient on admission according to the presence or absence of Health Care-Associated Infections between patients admitted to an Intensive Care Unit, Jataí, Goiás, Brazil, 2015

\begin{tabular}{|c|c|c|c|}
\hline Disease & $\begin{array}{c}\text { HAI* } \\
\text { patients } \\
n^{\alpha}(\%)\end{array}$ & $\begin{array}{c}\text { Patients } \\
\text { without HAI* } \\
\text { n }^{\alpha}(\%)\end{array}$ & value $^{p}$ \\
\hline Respiratory diseases & & & 0.13 \\
\hline Yes & 7 (33.3) & 7 (16.7) & \\
\hline No & $14(67.7)$ & $35(83.3)$ & \\
\hline Circulatory system diseases & & & 0.85 \\
\hline Yes & 7 (33.3) & 15 (35.7) & \\
\hline No & $14(67.7)$ & $27(64.3)$ & \\
\hline Digestive tract diseases & & & 0.78 \\
\hline Yes & $3(14.3)$ & $5(11.9)$ & \\
\hline No & $18(85.7)$ & $37(88.1)$ & \\
\hline Infectious and parasitic diseases & & & 0.07 \\
\hline Yes & $4(19)$ & $2(4.8)$ & \\
\hline No & $17(81)$ & $39(95.2)$ & \\
\hline Diseases of the urinary tract & & & 0.14 \\
\hline Yes & 0 & $4(9.5)$ & \\
\hline No & $21(100)$ & $38(90.5)$ & \\
\hline Neurological diseases & & & 0.14 \\
\hline Yes & 0 & $4(9.5)$ & \\
\hline No & $21(100)$ & $38(90.5)$ & \\
\hline Traumas & & & 0.09 \\
\hline Yes & 0 & $5(11.9)$ & \\
\hline No & $21(100)$ & $37(88.1)$ & \\
\hline Risk factors & & & 0.82 \\
\hline Yes & $17(81)$ & 33 (78.6) & \\
\hline No & $4(19)$ & $9(21.4)$ & \\
\hline
\end{tabular}

Table 3 - Hospital outcome according to the presence or absence of Health Care-Associated Infections of patients admitted to an Intensive Care Unit, Jataí, Goiás, Brazil, 2015

\begin{tabular}{|c|c|c|c|c|c|}
\hline Outcome & $\begin{array}{c}\text { HAI* } \\
\text { Patients } \\
\mathbf{n}^{\alpha}(\%)\end{array}$ & $\begin{array}{c}\text { Patients } \\
\text { without HAI* } \\
\mathbf{n}^{a}(\%)\end{array}$ & * $\mathbf{O R}^{1}$ & $\mathrm{Cl} 95 \%^{2}$ & $\begin{array}{c}p \\
\text { value }\end{array}$ \\
\hline Death & & & 12 & $2.953 ; 51.003$ & $<0.001$ \\
\hline Yes & $14(66.7)$ & $6(14.3)$ & & & \\
\hline No & $7(33.3)$ & $36(85.7)$ & & & \\
\hline Discharge to ward & & & 0.27 & $0.0727 ; 0.946$ & 0.021 \\
\hline Yes & $6(28.5)$ & $25(59.5)$ & & & \\
\hline No & $15(71.5)$ & $17(40.5)$ & & & \\
\hline Hospital discharge & & & 0 & $0 ; 3.893$ & 0.309 \\
\hline Yes & 0 & $2(4.8)$ & & & \\
\hline No & $21(100 \%)$ & $40(95.2)$ & & & \\
\hline $\begin{array}{l}\text { Transfer to another } \\
\text { institution }\end{array}$ & & & 0.18 & $0.004 ; 1.532$ & 0.088 \\
\hline Yes & $1(4.8)$ & $9(21.4)$ & & & \\
\hline No & $20(95.2)$ & 33 (78.6) & & & \\
\hline
\end{tabular}

Table 4 - Linear regression for the association between the cost and the presence of Health Care-Associated Infections among patients admitted to an Intensive Care Unit, Jataí, Goiás, Brazil, 2015

\begin{tabular}{lccc}
\hline & \multicolumn{3}{c}{ Hospital Cost } \\
& B & Cl 95\% & p value \\
\hline HAls* (without/with) & 4370.3 & $1225.1 ; 7515.4$ & 0.007 \\
Days of Hospital stay & 352.7 & $272.7 ; 432.7$ & $<0.001$ \\
Age (years) & 741.3 & $-1777.5 ; 3260.2$ & 0.557 \\
Sex (male/female) & -2646.9 & $-5093.0 ;-200.8$ & 0.035 \\
Ethnicity (white/non-white) & -2002.5 & $-4601.9 ; 596.9$ & 0.128 \\
Marital status & -495.2 & $-2832.2 ; 1841.8$ & 0.672 \\
(live/does not live with a partner) & & & \\
\hline
\end{tabular}

Note: HAI" - Health Care-Associated Infections; ' ${ }^{1}$ Confidence Interval.
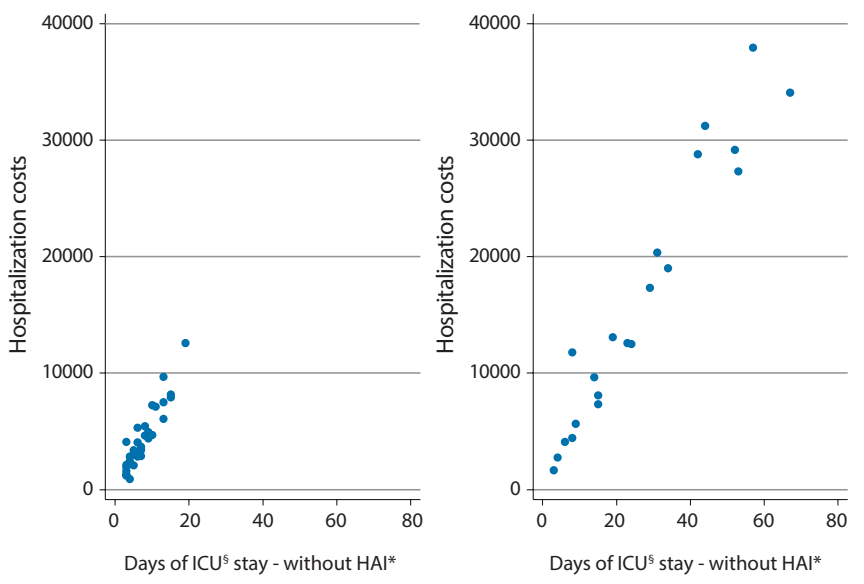

Note: HAl* - Health Care-Associated Infections; ICU ${ }^{\S}$ - Intensive Care Unit.

Figure 1 - Distribution of hospital costs and the number of days of hospital stay of patients with the presence or absence of Health Care-Associated Infections in an Intensive Care Unit in Jataí, Goiás, Brazil, 2015

All patients underwent invasive procedures during their hospitalization, including those without HAls. Respiratory infections were responsible for $71.4 \%$ of HAls (Pneumonia Associated with Mechanical Ventilation in $57.1 \%$ and Hospital Pneumonia, the one not associated with mechanical ventilation, in $14.3 \%$ of cases). Primary bloodstream infection was found in $14.3 \%$ of HAls; sepsis in $4.8 \%$ of cases; surgical site infection in $4.8 \%$; and urinary tract infection associated with the bladder catheter in $4.8 \%$. Among the HAl patients, 57.1\% had microbiological identification. The most frequent agent was Klebsiella pneumoniae, found in Pneumonia Associated with Mechanical Ventilation; $80 \%$ were resistant to the tested antimicrobials: Amoxicillin/Clavulanate, Ampicillin, Aztreonam, Cefepime Hydrochloride, Cefuroxime, Ciprofloxacin and Levofloxacin.

Concerning the outcome of hospitalized patients, $66.7 \%$ of those with HAls died in the hospital, $71.4 \%$ of them due to respiratory infections. Of the patients without $\mathrm{HAl}, 14.3 \%$ evolved to hospital death. HAI patients were 12 times more likely to die compared to patients who did not develop HAI [OR=12; Confidence Interval $95 \%(C 195 \%)=2.953 ; 51.003 ; p<0.001]$. HAI Patients $(28.5 \%)$ were less likely to be discharged from the ward than those without HAI (59.5\%) (OR=0.27; Cl95\% $=0.0727 ; 0.946 ; p=0.021)$ (Table 3).

A positive association was observed between hospital cost and HAl in the bivariate model ( $\beta=12068.84 ; p$-value $<0.001)$ and in the model adjusted by the covariates $(\beta=4370.3 ; p$-value $=0.007)$ (Table 4$)$.

\section{DISCUSSION}

The hospital cost and length of hospital stay for HAl patients were higher compared to patients who did not have HAls. Also, the most prevalent age group was of adult patients (less than 60 years) and the sex distribution was proportional. The most frequent topography was infections related to the respiratory system. Death was the most frequent outcome in cases of HAI and may have been a consequence of infections.

The causes of hospitalization of the studied patients were similar to the national evidence ${ }^{(13)}$. Moreover, the reasons for hospitalization depends on the hospital profile ${ }^{(14)}$. As for the risk factors presented in the patients' admission, the clinical conditions were similar and did not influence the diagnosis of HAI. 
As for the distribution of HAl topographies of patients hospitalized in the ICU, the similarity was observed with other evidence, in which the infection related to the respiratory system was the most frequent ${ }^{(15)}$. The worldwide rate of pulmonary infection in the ICU was reported in $64 \%$ and, in the groups of Brazilians, was shown the frequency of $71.2 \%$ of respiratory infection as the most frequent type of HAI in the ICUs, with gram-negative ones responsible for $72 \%$ of microorganisms isolated in infections, and as the main agent Pseudomonas, followed by Klebsiella(14,16).

As for the microbiological exams to identify the agents that cause infection in ICU patients, one study showed a low identification of these microorganisms (37.5\%) $)^{(17)}$ and another, similar to the present study, slightly higher $(50.7 \%)^{(16)}$. Laboratory diagnosis and appropriate microbiological identification of the causing agent of the disease are essential conducts to ensure control of the spread of infection-causing bacteria through the rational prescription of antibiotics and the use of clinical protocols, controlling bacterial resistance, morbidity and mortality ${ }^{(18)}$. The cost of antimicrobials in the ICU is high, and must be controlled and rationalized ${ }^{(19)}$. Through the implementation of an antimicrobial use monitoring program, it was possible to reduce the use of these drugs ${ }^{(20)}$ and, consequently, the costs. Epidemiological surveillance of multidrug-resistant microorganisms is one of the strategies for the control of HAls, and the effectiveness of public health actions should also be assessed, as well as the capacity and quality of microbiology laboratories, with the aim of providing the safety of health services in Brazil(21).

In cases of HAl, the most frequent outcome was death, with high lethality in pneumonia. Due to the high number of deaths among patients with HAls, we raised the hypothesis that it was a consequence of infections. Other studies showed a mortality rate of $34,6 \%{ }^{(17)} 57,6 \%{ }^{(22)}$ and $65,4 \%{ }^{(14)}$, lower data than those presented in the present study, indicating a possible relationship between infection and mortality ${ }^{(16)}$.

The cost of hospitalization was very high among HAl patients. In other studies, the costs of hospitalization for patients with HAls were, on average, 2 to 3 times higher than the costs for treating patients without $\mathrm{HAls} \mathrm{s}^{(7,10,12,23)}$. This evidence did not compare all types of HAls, so there may be an even greater difference in costs between patients with and without HAls.

Regarding hospital stay, in total days of hospital stay, the average of the present study was high compared to another study, which showed an average stay of 15 days for HAl patients and three days for patients without $\mathrm{HAI}^{(11)}$. However, the data in the present study were similar to the findings of Tiburcio's ${ }^{(12)}$ study, which identified an average hospital stay of 26.4 days for patients who acquired HAI in the ICU and 6,4 days for those without this diagnosis. They also converge to the results obtained by Pereira and collaborators ${ }^{(14)}$, who verified an average in ICU stay of 21,2 days for patients with HAls. The relative risk of acquiring $\mathrm{HAI}$ among patients who remain in the ICU for more than 30 days is 6.94 times greater than those who stay less than 5 days ${ }^{(24)}$.

There was no difference between the groups regarding invasive procedures and the use of antimicrobials. In another study, $100 \%$ of patients were submitted to invasive ${ }^{(14)}$ procedures. ICU patients are susceptible to infections due to critical condition and frequent invasive procedures, which create a gateway for HAl agents ${ }^{(24)}$. Furthermore, good practice strategies, such as professional training and improvements in working conditions, can increase patient safety within the ICU ${ }^{(25)}$.

It is necessary to adopt cost management that supports decision making and highlights the quality of spending. Currently, these expenses are being made with resolutions, treatments, hospitalizations or prevention of these $\mathrm{HAls}^{(26)}$. HAls prevention control in critically ill patients and avoided HAl incurs a lower cost ${ }^{(27)}$.

\section{Limitations of the study}

This study had limitations regarding the small number of articles about the HAI costs and case-control studies for comparison between patients with and without HAI to discuss the subject. The costs of hospitalizations were researched using a billing form that did not specify the spending on daily ICU, medication, and procedures. The indirect costs of hospitalization were also not evaluated. Thus, the HAl costs in the evaluated hospital may be even higher than those presented in this study, which highlights the need to calculate the costs of HAl for better allocation of financial resources.

\section{Contributions to health}

The accounting for infection costs makes it possible to review the prevention strategies that are being used to control HAls, promoting greater reflection among managers on the allocation of these resources to HAl prevention practices. Furthermore, it assists in decision making to increase the quality of health care, enabling a safer hospital stay for the patient. Also, the present study can contribute to increasing the knowledge of the scientific community regarding the economic impact of $\mathrm{HAI}$ in the ICU.

\section{CONCLUSIONS}

This study presented the characteristics of HAl in the institution under study and showed high financial costs of hospitalization of patients with diagnoses of infection compared to patients without a diagnosis of HAl. The survey of financial costs in the health system can favor economic management and the appropriate spending of resources for health promotion and prevention programs.

\section{REFERENCES}

1. Ministério da Saúde (BR). Portaria n²616/MS/GM, de 12 de maio de 1998. Diário Oficial da União [Internet]. Brasília (DF); 1998 [cited 2018 Jan 12]. Available from: http://bvsms.saude.gov.br/bvs/saudelegis/gm/1998/prt2616_12_05_1998.html

2. Oliveira HM, Silva CPR, Lacerda RA. Policies for control and prevention of infections related to healthcare assistance in Brazil: a conceptual analysis. Rev Esc Enferm USP. 2016;50(3):502-8. doi: 10.1590/S0080-623420160000400018 
3. Guest JF, Keating T, Gould D, Wigglesworth N. Modelling the annual NHS costs and outcomes attributable to healthcare-associated infections in England. BMJ Open. 2020;10:e033367. doi: 10.1136/bmjopen-2019-033367

4. World Health Organization (WHO). Guidelines on core components of infection prevention and control programmes at the national and acute health care facility level. 2016 [cited 2020 Feb 10]. Available from: https://www.who.int/gpsc/ipc-components/en/

5. Bartsch SM, McKinnell JA, Mueller LE, Miller LG, Gohil SK, Huang SS, et al. Potential economic burden of carbapenem-resistant Enterobacteriaceae (CRE) in the United States. Clin Microbiol Infect. 2017;23(1):48.e9-48.e16. doi: 10.1016/j.cmi.2016.09.003

6. Leoncio JM, Almeida VF, Ferrari RAP, Capobiango JD, Kerbauy G, Tacla MTGM. Impact of healthcare-associated infections on the hospitalization costs of children. Rev Esc Enferm USP. 2019;53:e03486. doi: 10.1590/S1980-220X2018016303486

7. Abdelmoneim H, Ibrahim H, Ahmed A, Mohammed K. Incidence of central line-associated blood steam infection in Pediatric Intensive Care Unit (PICU). Egypt J Hosp Med. 2020;78(1):136-141. doi: 10.12816/EJHM.2020.68483

8. Padoveze MC, Fortaleza CM, Kiffer C, Barth AL, Carneiro IC, Giamberardino HI, et al. Structure for prevention of health care-associated infections in Brazilian hospitals: a countrywide study. Am J Infect Control. 2016;1;44(1):74-9. doi: 10.1016/j.ajic.2015.08.004

9. Primo MGB, Guilarde AO, Martelli CMT, Batista LJA, Turchi MD. Healthcare-associated Staphylococcus aureus bloodstream infection: length of stay, attributable mortality, and additional direct costs. Braz J Infect Dis. 2012;16(6):503-9. doi: 10.1016/j.bjid.2012.10.001

10. Nangino GO, Oliveira CD, Correia PC, Machado NM, Dias AT. Financial impact of nosocomial infections in the intensive care units of a charitable hospital in Minas Gerais, Brazil. Rev Bras Ter Intensiva. 2012;24(4):357-61. doi: 10.1590/S0103-507X2012000400011

11. Tibúrcio AS. Economic costs of healthcare-related infections acquired in an Intensive Care Unit. J Infect Control [Internet]. 2019 [cited 2020 Jan 6];8(1):08-11. Available from: http://jic-abih.com.br/index.php/jic/article/view/242

12. Kim A, Lee JA, Park HS. Health behaviors and illness according to marital status in middle-aged Koreans. J Public Health. 2018;40(2):e99-e106. doi:10.1093/pubmed/fdx071

13. Pereira BS, Tomasi E. Instrumento de apoio à gestão regional de saúde para monitoramento de indicadores de saúde. Epidemiol Serv Saude. 2016;25(2):411-8. doi: 10.5123/S1679-49742016000200019

14. Pereira FGF, Chagas ANS, Freitas MMC, Barros LM, Caetano JA. Characterization of infections related to health care in the intensive care unit. Vigil Sanit Debate. 2016;4(1):70-7. doi: 10.3395/2317-269x.00614

15. Santos AV, Silva MRP, Carvalho MM, Carvalho LRB, Moura MEB, Landim CAP. Perfil das infecções hospitalares nas unidades de terapia intensiva de um hospital de urgência. Rev Enferm UFPE. 2016;10(Supl.1):194-201. doi: 10.5205/reuol.7901-80479-1-SP.1001sup201601

16. Silva E, Dalfior Jr L, Fernandes HS, Moreno R, Vincent JL. Prevalence and outcomes of infections in Brazilian ICUs: a subanalysis of EPIC II study. Rev Bras Ter Intensiva. 2012;24(2):143-150. doi: 10.1590/S0103-507X2012000200008

17. Bergamim-Hespanhol LA, Ramos SCS, Ribeiro Jr OC, Araújo TS, Martins AB. Infección relacionada con la Asistencia a la Salud en Unidad de Cuidados Intensivos Adulto. Enferm Glob. 2018;18(1):215-54. doi: 10.6018/eglobal.18.1.296481

18. Sociedade Brasileira de Patologia Clínica/Medicina Laboratorial. Recomendações da Sociedade Brasileira de Patologia Clínica/Medicina Laboratorial (SBPC/ML): boas práticas em microbiologia clínica [Internet]. Barueri: Manole; 2015 [cited 2020 Feb 13]. Available from: http:// www.sbpc.org.br/upload/conteudo/Microbiologia.pdf

19. Lara FLO, Antunes AV, Mendes-Rodrigues C, Felice IO. Custos da antibiotioterapia em pacientes adultos com infecção hospitalar em uma unidade de terapia intensiva. Rev Prev Infec e Saúde. 2017;3(4):8-14. doi: 10.26694/repis.v3i4.6621

20. Silva FAA, Trajano LPB, Nogueira NC, Sousa KS, Coêlho ML, Nunes MRCM. Análise do consumo e custo de antifúngicos em um Hospital Universitário. Rev Ciênc Saúde [internet]. 2018;1(1):61-8. doi: 10.26694/2595-0290.1161-68

21. Ministério da Saúde (BR). Agência Nacional de Vigilância Sanitária. Programa Nacional de Prevenção e Controle de Infecções Relacionadas à Assistência à Saúde (2016-2020). Brasília. 2016 [cited 2018 Ago 24]. Available from: https://www20.anvisa.gov.br/segurancadopaciente/ index.php/publicacoes/item/pnpciras-2016-2020

22. Nogueira PSF, Moura ERF, Costa MMF, Monteiro WMS, Brondi L. Perfil da infecção hospitalar em um hospital universitário. Rev Enferm UERJ [Internet]. 2009 [cited 2018 Aug 25];17(1):96-101. Available from: http://www.facenf.uerj.br/v17n1/v17n1a18.pdf

23. Al-Rawajfah OM, Cheema J, JB Hewitt, Hweidj IM, Musallam E. Laboratory-confirmed, health care-associated bloodstream infections in Jordan: a matched cost and length of stay study. Am J Infect Control. 2013;41(7):607-11. doi: 10.1016/j.ajic.2012.08.014

24. Figueiredo DA, Vianna RPT, Nascimento JA. Epidemiologia da infecção hospitalar em uma Unidade de Terapia Intensiva de um Hospital Público Municipal de João Pessoa-PB. Rev Bras Ciênc Saúde. 2013;17(3):233-240. doi: 10.4034/RBCS.2013.17.03.04

25. Duarte SDCM, Azevedo SS, Muinck GDC, Costa TFD, Cardoso MMVN, Moraes JRMM. Best Safety Practices in nursing care in Neonatal Intensive Therapy. Rev Bras Enferm. 2020;73(2):e20180482. doi: 10.1590/0034-7167-2018-0482

26. Ministério da Saúde (BR). Organização Pan-Americana da Saúde. Introdução à Gestão de Custos em Saúde [Internet]. Brasília: Editora do Ministério da Saúde. 2013 [cited 2020 Feb 08]. Available from: http://bvsms.saude.gov.br/bvs/publicacoes/introducao_gestao_custos_ saude.pdf

27. Combariza JF, Toro LF, Orozco JJ, Arango M. Cost-effectiveness analysis of interventions for prevention of invasive aspergillosis among leukemia patients during hospital construction activities. Eur J Haematol. 2018;100(2):140-146. doi: 10.1111/ejh.12991 